\title{
Pemetaan Kawasan Rawan Tanah Longsor di Kecamatan Gedangsari, Kabupaten Gunungkidul, Yogyakarta dengan Metode Analytical Hierarchy Process (AHP)
}

\author{
Wawan Budianta \\ Departemen Geologi, Fakultas Teknik, Universitas Gadjah Mada, Mlati, Sleman, Daerah Istimewa Yogyakarta, \\ Indonesia
}

Submisi: 07 Mei 2019 ; Revisi: 27 April 2020; Penerimaan: 05 Mei 2020

Kata Kunci:
Kemiringan
lereng
Kerawanan
Litologi
Mitigasi
Tata guna lahan

Keywords:

Land use

Lithology

Mitigation

Slope

Vulnerability

\begin{abstract}
Abstrak Kecamatan Gedangsari, Gunungkidul, Yogyakarta merupakan daerah yang didominasi oleh perbukitan dan sering mengalami tanah longsor. Penelitian ini bertujuan untuk melakukan pemetaan kerawanan tanah longsor di daerah penelitian dengan metode Analytical Hierarchy Process (AHP). Parameter yang digunakan dalam pembobotan dan perhitungan AHP meliputi parameter jenis batuan atau litologi, kemiringan lereng, dan tata guna lahan. Hasil perhitungan pembobotan AHP menunjukkan bahwa kemiringan lereng menduduki peringkat paling tinggi, disusul oleh jenis batuan, dan tata guna lahan. Peta kerawanan tanah longsor menunjukkan bahwa Desa Tegalrejo dan Mertelu didominasi oleh zona kerawanan tanah longsor yang tinggi, sedangkan desa yang lain berada di zona kerawanan sedang hingga rendah. Hasil pemetaan ini dapat digunakan oleh masyarakat dan pemerintah setempat sebagai dasar tindakan mitigasi dan pengembangan wilayah.

Abstract Gedangsari Sub-District in Gunungkidul District, Yogyakarta, is dominated by hilly morphology and landslides have been found commonly in the area. The purpose of this study was to create a landslide susceptibility map by using the Analytical Hierarchy Process (AHP) method. The parameters used in the weighting of the analytical hierarchy process calculation were including rock type or lithology, slope, and land use parameters. The result of the AHP calculation showed that the slope occupies the highest criterion, followed by lithology and land use. The landslide susceptibility mapping indicated that the most landslide-vulnerable zone was located in Tegalrejo and Mertelu Village, meanwhile another area mostly has a low to a moderate region of landslide vulnerability. The map produced in this study can be used for the public and government for mitigation purposes as well as regional planning.
\end{abstract}

\section{PENDAHULUAN}

Indonesia adalah salah satu negara yang rawan mengalami bencana hidrometeorologi, yaitu bencana yang disebabkan oleh perubahan iklim dan cuaca. Sekira 1.681 bencana yang menyebabkan korban jiwa 259 orang (sebagian besar merupakan korban bencana tanah longsor) di antaranya terjadi di Jawa Tengah dan Daerah Istimewa Yogyakarta (Nugroho, 2016; BNPB, 2012). Peraturan Menteri Dalam Negeri No. 33 Tahun 2006 menyebutkan beberapa hal yang harus diperhatikan dalam upaya mitigasi bencana, antara lain tersedianya informasi dan peta kerawanan bencana untuk setiap jenis bencana, sosialisasi kepada masyarakat dalam menghadapi bencana, pemahaman cara penyelamatan diri jika terjadi bencana, serta pengaturan dan penataan kwasan rawan bencana.

Lokasi penelitian ini terletak di beberapa desa di Kecamatan Gedangsari, Kabupaten Gunungkidul, Provinsi Daerah Istimewa Yogyakarta. Beberapa desa di Kecamatan Gedangsari merupakan daerah rawan tanah longsor sehingga tingkat kerawanan wilayah terhadap tanah longsor perlu diketahui (Gambar 1).

ISSN 2460-9447 (print), ISSN 2541-5883 (online)

${ }^{*}$ Corresponding author: Wawan Budiarta

${ }^{1}$ Departemen Geologi, Fakultas Teknik, Universitas Gadjah Mada, Jl. Grafika No.2, Senolowo, Mlati, Sleman 55284, Daerah Istimewa Yogyakarta, Indonesia

Email:wbudianta@mail.ugm.ac.id 
Penelitian ini merupakan bagian dari kegiatan pengabdian kepada masyarakat yang bertujuan untuk membuat peta kerawanan tanah longsor dengan metode Analytical Hierarchy Process (AHP) di daerah tersebut. Hasil penelitian ini diharapkan dapat memberikan rekomendasi mitigasi bencana tanah longsor di daerah penelitian.

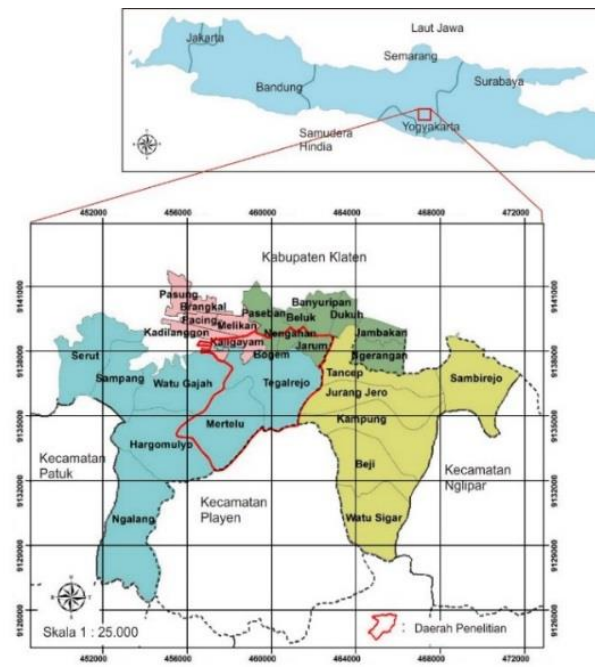

Gambar 1. Peta lokasi penelitian dalam kegiatan pengabdian kepada masyarakat (dimodifikasi dari peta administrasi Kabupaten Gunungkidul, 2018)

Kerawanan tanah longsor terjadi di daerah yang memiliki kemiringan lereng atau kondisi morfologi yang curam, adanya bidang luncur yang kedap air di lapisan bawah permukaan tanah, dan terdapatnya air tanah di atas lapisan kedap air tersebut. Faktor yang memengaruhi kerawanan tanah longsor dapat dibagi menjadi dua, yaitu faktor alam dan pengaruh aktivitas manusia. Faktor alam meliputi besaran curah hujan, kemiringan lereng, kondisi geologi atau batuan, keberadaan struktur geologi, seperti patahan atau retakan, kedalaman tanah sampai lapisan kedap, dan faktor aktivitas manusia yang meliputi penggunaan lahan, keberadaan infrastruktur, serta kepadatan permukiman (Karnawati, 2005).

Penelitian tentang pemetaan kerawanan tanah longsor dengan metode AHP sudah banyak dilakukan oleh pada peneliti dan hasilnya bisa diandalkan (Althuwaynee et al., 2014; Yalcin, 2008; Park et al., 2012; Oh \& Lee, 2011; Mandal \& Mandal, 2018; Nahayo et al., 2019). AHP merupakan analisis pengambilan keputusan berbasis sistem informasi geografis (SIG) yang populer karena kemampuannya untuk mengintegrasikan sejumlah data heterogen. AHP juga memberikan kemudahan dalam mendapatkan bobot alternatif yang sangat besar dan dapat diterapkan untuk pengambilan keputusan dalam berbagai masalah.

AHP merupakan metode yang mempertimbangan banyak faktor objektif dan subjektif dalam alternatif ranking. Selain itu, AHP dapat membantu proses pengambilan keputusan melalui model keputusan yang hierarkis. Metode AHP menggunakan matriks perbandingan berpasangan yang membentuk matriks timbal balik dalam mengubah data rasio kualitatif. Eigenvalue digunakan untuk mengakses bobot akhir dari kriteria dan mengukur tingkat konsistensi yang didapatkan melalui indeks konsistensi (Vahidnia et al., 2009; Saaty, 2008; Chen et al., 2009; Eldrandaly, 2013).

\section{METODE}

Penelitian ini diawali dengan pengambilan dan verifikasi data lapangan yang meliputi satuan batuan atau litologi, kemiringan lereng, dan tata guna lahan. Parameter-parameter tersebut kemudian dianalisis dengan metode AHP (Gambar 2). Dalam pembobotan tiap parameter berlaku hukum aksioma reciprocal, yaitu apabila suatu parameter dinilai lebih penting lima kali dibandingkan dengan parameter lain, parameter lebih penting menjadi $1 / 5$ kalinya. Apabila suatu parameter sama pentingnya dengan parameter lain, masing-masing bernilai 1. Apabila proses pembobotan telah selesai, langkah selanjutnya adalah penyusunan matriks perbandingan berpasangan untuk normalisasi bobot tingkat kepentingan pada tiap-tiap parameter pada masing-masing hierarkinya. Setelah matriks perbandingan berpasangan disusun selanjutnya dilakukan uji konsistensi pada pembobotan dan tolak ukur dengan consistency index (CI) yang merupakan perbandingan antara ratio index (RI) atau consistency ratio $(\mathrm{CR})$. Detail pembobotan dan perhitungan dapat dilihat pada Tabel 1 dan Tabel 2

Tabel 1. Skala Kepentingan

\begin{tabular}{lcccc}
\hline X & Parameter & Kelerengan & $\begin{array}{c}\text { Satuan } \\
\text { Batuan }\end{array}$ & $\begin{array}{c}\text { Tata } \\
\text { Guna } \\
\text { Lahan }\end{array}$ \\
\hline $\begin{array}{l}\text { Kelerengan } \\
\text { Satuan }\end{array}$ & 4 & 1 & $1 / 4$ & $1 / 2$ \\
$\begin{array}{l}\text { Batuan } \\
\text { Tata Guna }\end{array}$ & 1 & 4 & 1 & 2 \\
Lahan & 2 & 2 & $1 / 2$ & 1 \\
\hline
\end{tabular}

Tabel 1 menunjukkan skala kepentingan. Warna abuabu tua adalah header untuk parameter yang terbagi ke dalam baris $\mathrm{X}$ dan $\mathrm{Y}$, yang terdiri atas warna abu-abu muda, yaitu kemiringan lereng, satuan batuan, dan tata guna lahan. Warna jingga tua adalah bobot yang terdiri atas nilai bobot untuk masing-masing parameter yang ditandai dengan warna jingga muda. Warna putih adalah hasil perbandingan antara nilai Y terhadap X. 
Tabel 2. Matriks perbandingan berpasangan

\begin{tabular}{|c|c|c|c|c|c|}
\hline $\mathrm{X}$ & Parameter & Kelere & $\begin{array}{l}\text { Satuan } \\
\text { Batuan }\end{array}$ & $\begin{array}{r}\text { Tata } \\
\text { Guna } \\
\text { Lahan } \\
\end{array}$ & $\begin{array}{l}\text { Nilai } \\
\text { Kepentin } \\
\text { gan }\end{array}$ \\
\hline Parameter & Bobot & 4 & 1 & 2 & \\
\hline Kelerengan & 4 & 1 & 0,25 & 0,5 & 0,571 \\
\hline $\begin{array}{l}\text { Satuan } \\
\text { Batuan }\end{array}$ & 1 & 4 & 1 & 2 & 0,143 \\
\hline $\begin{array}{l}\text { Tata Guna } \\
\text { Lahan }\end{array}$ & 2 & 2 & 0,5 & 1 & 0,286 \\
\hline Jumlah & & 7 & 1,75 & 3,5 & 1,000 \\
\hline \multicolumn{3}{|c|}{ Principle Eigen Value $\chi_{\max }$} & $=$ & & 4 \\
\hline \multicolumn{3}{|c|}{ Consistency Index (CI) } & $=$ & & 0 \\
\hline \multicolumn{3}{|c|}{ Consistency Ratio (CR) } & $=$ & & $0 \%$ \\
\hline
\end{tabular}

Tabel 2 menunjukkan matriks perbandingan berpasangan. Warna abu-abu tua adalah header untuk parameter yang terbagi ke dalam baris $\mathrm{X}$ dan $\mathrm{Y}$, yang terdiri atas warna abu-abu muda, yaitu kemiringan lereng, satuan batuan, dan tata guna lahan. Warna jingga tua adalah header bobot yang terdiri atas nilai bobot untuk masing-masing parameter, yang ditandai dengan warna jingga muda. Warna putih, hijau, dan kuning adalah hasil perbandingan antara nilai $\mathrm{Y}$ terhadap $\mathrm{X}$. Warna putih, misalnya, adalah parameter satuan batuan 0,25 kali lebih penting daripada parameter kemiringan lereng, parameter tata guna lahan 0,5 kali lebih penting daripada parameter kemiringan lereng, dan parameter tata guna lahan 2 kali lebih penting daripada parameter satuan batuan. Dalam hal ini, nilai kepentingan adalah bobot parameter berbanding jumlah bobot.

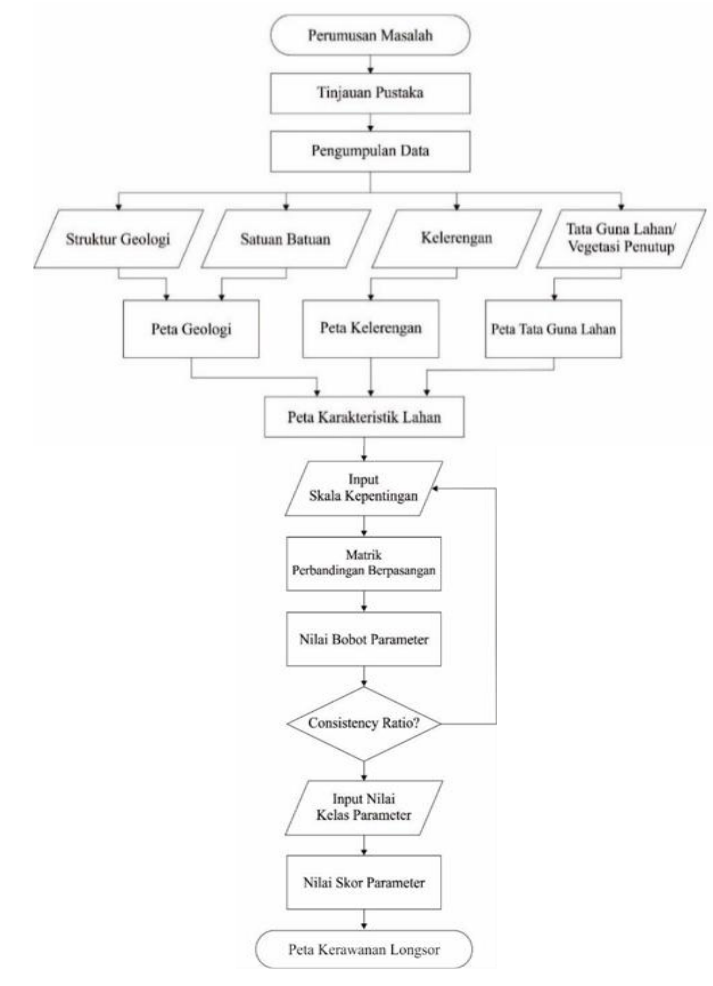

Gambar 2. Kerangka penelitian
Analisis yang dilakukan dalam penelitian ini adalah analisis dari data sekunder yang meliputi:

a. peta geologi regional lembar Surakarta dan Giritontro, skala 1:100.000 (Surono et al., 1992),

b. peta tata guna lahan dari Badan Informasi Geospasial, skala 1:25.000, dan

c. peta rupa bumi, skala 1:25.000 dari Badan Informasi Geospasial.

Peta-peta tersebut kemudian diolah menggunakan aplikasi SIG serta pertimbangan dari data lapangan yang akan menghasilkan output sebagai berikut.

a. Peta litologi, skala 1:25.000

Peta ini merupakan peta geologi yang didapatkan dengan membuat satuan dan menyajikan aspek satuan batuan (litologi), jurus dan kemiringan batuan, serta struktur geologi.

b. Peta tata guna lahan, skala 1:25.000

Peta ini disajikan sebagai data pada pemetaan yang dikeluarkan oleh Badan Informasi Geospasial tahun 2018.

c. Peta kemiringan lereng, skala, 1:25.000

Peta ini merupakan peta hasil analisis yang berfokus pada perhitungan raster dari kontur kemiringan lereng. Peta kontur dalam format shp (line) yang menunjukkan elevasi diubah menjadi raster menggunakan tool "slope" di ArcGIS untuk menunjukkan pola kemiringan lereng.

\section{HASIL DAN PEMBAHASAN}

Hasil analisis pada peneltian ini meliputi lima peta, yaitu peta litologi atau jenis batuan, peta tata guna lahan, peta kemiringan lereng (slope), peta karakteristik lahan, dan peta kerawanan tanah longsor.

\subsection{Peta litologi atau jenis batuan}

Peta jenis litologi atau batuan daerah penelitian (Gambar 3) terbagi menjadi tiga satuan batuan, yaitu batu pasir tufan masif, batu pasir berlapis, dan endapan aluvial. Nilai potensi kerawanan tanah longsor yang didasarkan pada satuan batuan secara komparasi kualitatif digambarkan pada Gambar 4.

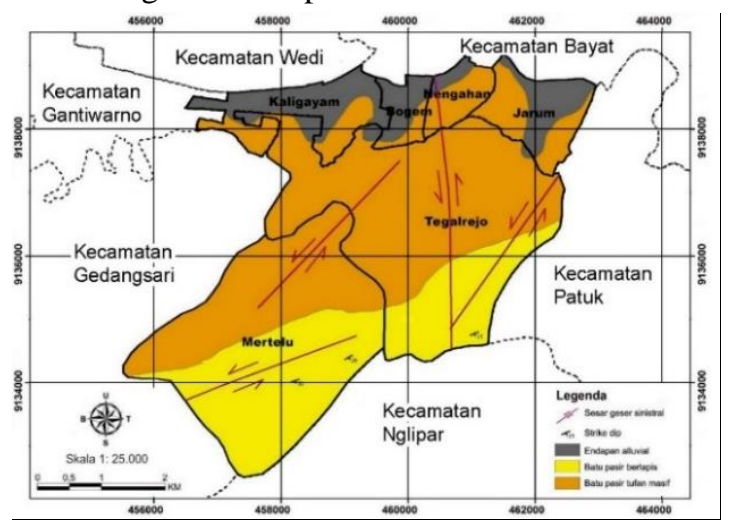

Gambar 3. Peta litologi atau jenis batuannya 


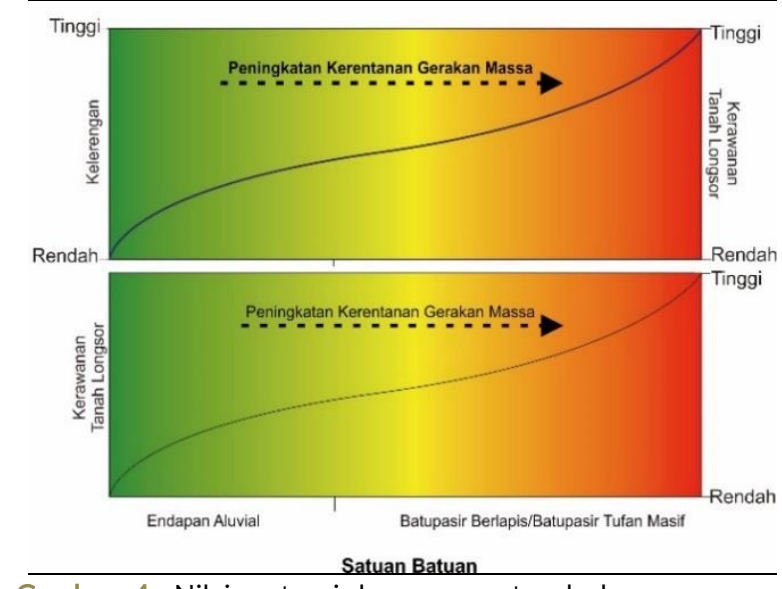

Gambar 4. Nilai potensi kerawanan tanah longsor secara komparasi kualitatif

Batu pasir tufan masif dan batu pasir berlapis memiliki nilai potensi tanah longsor yang sama besar, sedangkan endapan aluvial memiliki potensi tanah longsor yang lebih kecil daripada batuan lainnya.

\subsection{Peta tata guna lahan}

Peta tata guna lahan daerah penelitian dibagi dalam empat satuan. Satuan pertama adalah satuan kebun yang merupakan satuan dengan tanaman berbatang besar sebagai tanaman budi daya utama sehingga dapat menjadi tanaman penguat lereng yang baik. Satuan kedua dan ketiga adalah satuan ladang dan sawah yang memiliki tanaman budi daya utama berupa tanaman berbatang kecil sehingga tidak dapat digunakan sebagai tanaman penguat. Satuan ini umumnya terletak di perbukitan dalam bentuk terasering dengan tanaman penguat sehingga dapat mengurangi risiko tanah longsor. Satuan keempat adalah satuan permukiman yang merupakan satuan tanpa penstabil lereng meskipun di beberapa tempat terdapat konstruksi dinding penahan (retaining wall) yang terbuat dari beton. Oleh karena itu, konstruksi dinding penahan ini dapat diabaikan karena jumlahnya yang sedikit dan hanya tersebar di beberapa titik (Gambar 5).

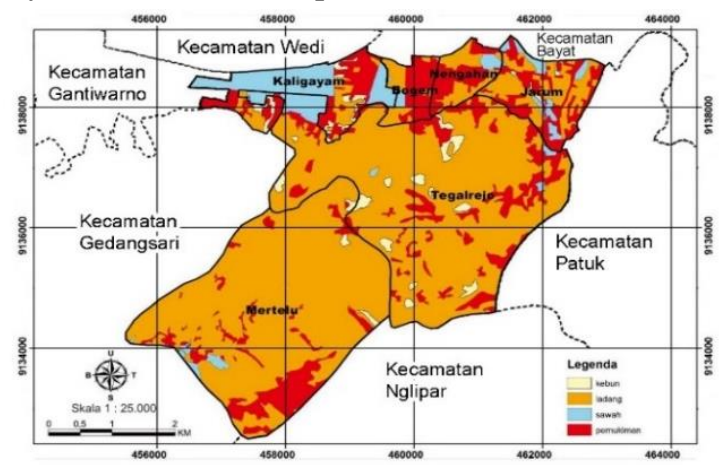

Gambar 5. Peta tata guna lahan

\subsection{Peta kemiringan lereng}

Peta kemiringan lereng (Gambar 6) merupakan hasil analisis dari peta kontur topografi yang dibuat berdasarkan perhitungan raster dari kontur kemiringan lereng yang kemudian disajikan dalam zona-zona berdasarkan besar sudut kemiringan lereng. Pembagian zona berdasarkan sudut kemiringan lereng adalah sebagai berikut.

1. Zona kemiringan lereng tinggi yang memiliki sudut kemiringan lereng $>40^{\circ}$

2. Zona kemiringan lereng sedang yang memiliki sudut kemiringan lereng $30^{\circ}-40^{\circ}$

3. Zonasi kemiringan lereng rendah yang memiliki sudut kemiringan lereng $<30^{\circ}$

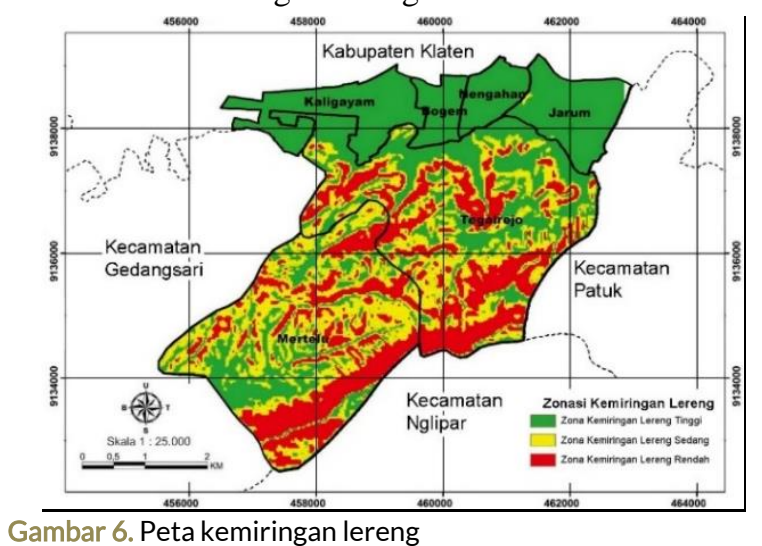

\subsection{Pembobotan}

Pembobotan parameter dilakukan dengan pendekatan yang mengubah nilai kualitatif pada peta karakteristik lahan menjadi nilai kuantitatif (Tabel 3, Tabel 4, Tabel 5, dan Tabel 6). Pendekatan ini dilakukan dengan memperkirakan nilai prioritas setiap parameter dalam metode AHP. Pembobotan meliputi tiga parameter, yaitu kemiringan lereng, satuan batuan, dan vegetasi penutup. Pembobotan dilakukan dengan menentukan skala kepentingan (Tabel 3) yang mempertimbangkan aspek judgement atau rasionalitas, menghitung matriks perbandingan berpasanganan, dan menentukan nilai bobot dari matriks perbandingan berpasangan (Tabel 4). Nilai CR (Consistency Ratio) yang diperoleh sebesar 0\%. Berdasarkan ketentuan dalam perhitungan AHP, pembobotan dengan nilai $\mathrm{CR} \leq 10 \%$ dapat diterima sehingga nilai $\mathrm{CR}$ yang diperoleh dapat diterima.

Tabel 3. Skala kepentingan

\begin{tabular}{lc}
\hline \multicolumn{1}{c}{ Parameter } & Skala kepentingan \\
\hline Kemiringan lereng & 4 \\
Satuan batuan & 1 \\
Tata guna lahan & 2 \\
\hline
\end{tabular}

Tabel 4. Nilai bobot parameter

\begin{tabular}{lc}
\hline \multicolumn{1}{c}{ Parameter } & Skala kepentingan \\
\hline Kemiringan lereng & 0,571 \\
Satuan batuan & 0,143 \\
Tata guna lahan & 0,286
\end{tabular}


Tabel 5. Klasifikasi kerawanan tanah longsor

\begin{tabular}{|c|c|c|c|c|c|}
\hline \multicolumn{2}{|c|}{ Zona kerawanan } & \multicolumn{2}{|c|}{ Nilai Skoring } & \multicolumn{2}{|c|}{ Simbol Warna } \\
\hline \multicolumn{2}{|c|}{ Tinggi } & \multicolumn{2}{|c|}{$2,238-2,714$} & & \\
\hline \multicolumn{2}{|l|}{ Sedang } & \multicolumn{2}{|c|}{$1,762-2,237$} & & \\
\hline \multicolumn{2}{|l|}{ Rendah } & \multicolumn{2}{|c|}{$1,286-1,761$} & & \\
\hline \multicolumn{6}{|c|}{ Tabel 6. Nilai skoring } \\
\hline Parameter & Ke & & Nilai & Bobot & Skor \\
\hline \multirow[t]{3}{*}{$\begin{array}{l}\text { Kemiringan } \\
\text { lereng }\end{array}$} & \multicolumn{2}{|c|}{$\begin{array}{l}\text { Tinggi } \\
\left(>40^{\circ}\right)\end{array}$} & 3 & 0,571 & 1,713 \\
\hline & \multicolumn{2}{|c|}{$\begin{array}{l}\text { Sedang } \\
\left(30^{\circ}-40^{\circ}\right)\end{array}$} & 2 & & 1,142 \\
\hline & \multicolumn{2}{|c|}{$\begin{array}{l}\text { Rendah } \\
\left(<30^{\circ}\right)\end{array}$} & 1 & & 0,571 \\
\hline \multirow[t]{3}{*}{$\begin{array}{l}\text { Satuan } \\
\text { batuan }\end{array}$} & \multicolumn{2}{|c|}{$\begin{array}{l}\text { Endapan } \\
\text { aluvial }\end{array}$} & 3 & 0,143 & 0,429 \\
\hline & \multicolumn{2}{|c|}{$\begin{array}{l}\text { Batu pasir } \\
\text { berlapis }\end{array}$} & 1 & & 0,143 \\
\hline & \multicolumn{2}{|c|}{$\begin{array}{l}\text { Batu pasir } \\
\text { tufan masif }\end{array}$} & 1 & & 0,143 \\
\hline \multirow{3}{*}{$\begin{array}{l}\text { Tata guna } \\
\text { lahan }\end{array}$} & \multicolumn{2}{|c|}{ Permukiman } & 3 & 0,286 & 0,858 \\
\hline & \multicolumn{2}{|c|}{$\begin{array}{l}\text { ladang atau } \\
\text { sawah }\end{array}$} & 2 & & 0,572 \\
\hline & \multicolumn{2}{|c|}{ Kebun } & 1 & & 0,286 \\
\hline
\end{tabular}

\subsection{Peta karakteristik lahan}

Peta karakteristik lahan merupakan peta overlay dari peta jenis batuan atau litologi, peta tata guna lahan, dan peta kemiringan lereng (Gambar 7). Sebelum dilakukan overlay, langkah yang dilakukan adalah penyatuan satuan yang memiliki nilai skor/skala kepentingan yang sama dalam satu parameter. Pada peta ini terdapat lima belas satuan yang masing-masing memiliki kondisi geologi dan/atau tata guna lahan dan/atau kemiringan lereng yang berbeda dan diberi simbol warna yang berbeda (Tabel 7).

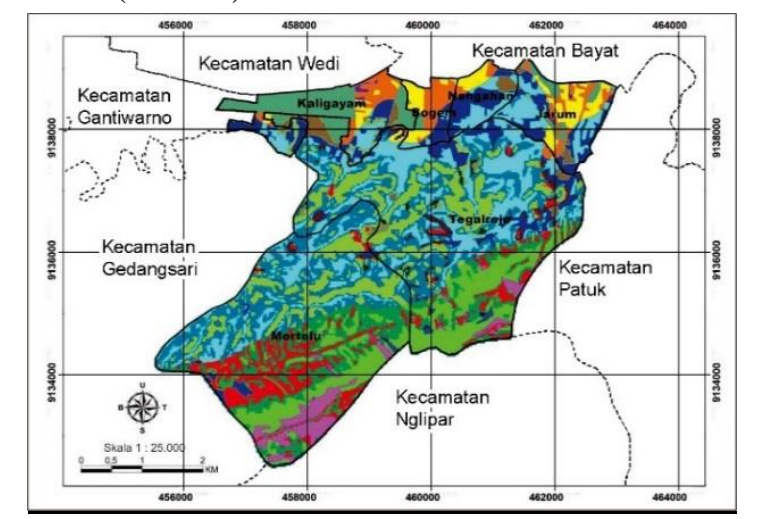

Gambar 7. Peta karakteristik lahan

Atribut terdiri atas 6 huruf yang setiap 2 huruf (terdiri atas huruf kapital pertama dan huruf kecil kedua) menunjukkan kelas dan merujuk pada Tabel 6 . Huruf kapital pertama terdiri atas 3 huruf, yaitu B, T, dan $\mathrm{K}$ yang menunjukkan parameter yang merujuk pada Tabel 6. Huruf B untuk satuan batuan, T untuk tata guna lahan, dan $\mathrm{K}$ untuk kemiringan lereng.

\begin{tabular}{lccccc}
\hline Legenda* & Atribut** & $\begin{array}{c}\text { Skor } \\
\text { Kemirin } \\
\text { gan } \\
\text { lereng }\end{array}$ & $\begin{array}{c}\text { Skor } \\
\text { satuan } \\
\text { batuan }\end{array}$ & $\begin{array}{c}\text { Skor } \\
\text { tata } \\
\text { guna } \\
\text { lahan }\end{array}$ & $\begin{array}{c}\text { Total } \\
\text { skor ** }\end{array}$ \\
\hline & TlBbKl & 0,572 & 0,143 & 0,571 & 1,286 \\
\hline & TlBbKc & 0,572 & 0,143 & 1,713 & 2,428 \\
\hline & TlBbKs & 0,572 & 0,143 & 1,142 & 1,857 \\
\hline & TsBbKc & 0,858 & 0,143 & 1,713 & 2,714 \\
\hline & TsBbKs & 0,858 & 0,143 & 1,142 & 2,143 \\
\hline & TlBtKs & 0,572 & 0,143 & 1,142 & 1,857 \\
\hline & TlBtKl & 0,572 & 0,143 & 0,571 & 1,286 \\
\hline & TlBtKc & 0,572 & 0,143 & 1,713 & 2,428 \\
\hline & TlBeKl & 0,572 & 0,429 & 0,571 & 1,572 \\
\hline & TsBeKl & 0,858 & 0,429 & 0,571 & 1,858 \\
\hline & TsBtKl & 0,858 & 0,143 & 0,571 & 1,572 \\
\hline & TsBeKl & 0,858 & 0,429 & 0,571 & 1,858 \\
\hline & & 0,858 & 0,143 & 0,571 & 1,572 \\
\hline
\end{tabular}

*Warna menunjukkan satuan dalam Peta Karakteristik Lahan

**Warna menunjukkan klasifikasi kerawanan tanah longsor berdasarkan skor

Keterangan Atribut:

$B b=$ Batu pasir berlapis

$B t=$ Batu pasir tufan masif

$B e=$ Endapan aluvial

$K c=$ Sudut kemiringan lereng ting $i$

$K s=$ Sudut kemiringan lereng sedang

$K l=$ Sudut kemiringan lereng rendah

$T l=$ Tata guna lahan ladang

$T k=$ Tata guna lahan kebun

Ts = Tata guna lahan sawah

\subsection{Peta kerawanan tanah longsor}

Peta kerawanan tanah longsor adalah bentuk spasial atau visualisasi dari hasil skoring yang dilakukan pada Tabel 7. Peta ini menggambarkan potensi tanah longsor yang ada di daerah penelitian (Gambar 8). Peta kerawanan tanah longsor memiliki tiga zona yang didasarkan pada klasifikasi di Tabel 3. Perkiraan arah dari potensi tanah longsor dilakukan berdasarkan tinjauan dari arah kemiringan lereng pada peta kemiringan lereng (Gambar 6). Gambar 8 menunjukkan zona kerawanan tanah longsor tinggi yang sebagian besar berada di Desa Tegalrejo dan Mertelu. Adapun desa yang lain sebagian besar mempunyai kerawanan sedang hingga rendah. 


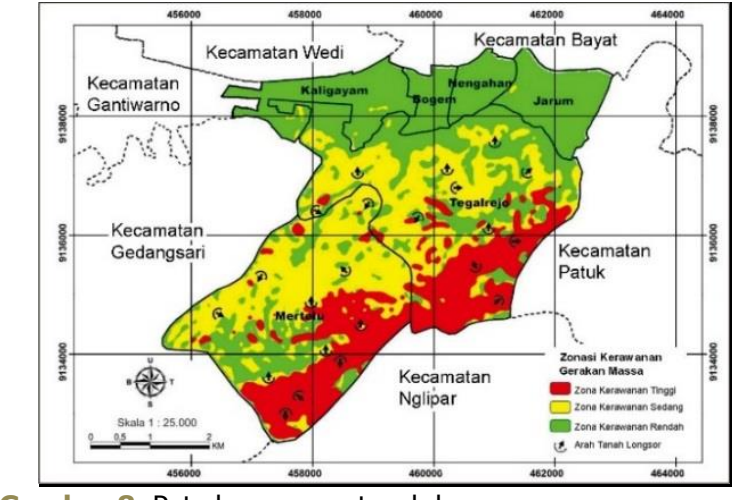

Gambar 8. Peta kerawanan tanah longsor

\section{KESIMPULAN}

Zona kerawanan tanah longsor tinggi di daerah penelitian sebagian besar berlokasi di Desa Tegalrejo dan Mertelu yang wilayahnya didominasi oleh daerah dengan kemiringan lereng tinggi, sedangkan desa yang lain sebagian besar mempunyai kerawanan sedang hingga rendah. Peta kerawanan tanah longsor di daerah penelitian ini dapat digunakan oleh masyarakat dan pemerintah setempat sebagai dasar tindakan mitigasi dan pengembangan wilayah di masa yang akan datang.

\section{UCAPAN TERIMA KASIH}

Penulis mengucapkan terima kasih kepada Pemerintah Daerah Kabupaten Gunungkidul dan Kecamatan Gedangsari, berserta seluruh aparat yang terkait, yang sudah memberikan fasilitas dan dukungan selama pelaksanaan kegiatan. Penulis mengucapkan terima kasih kepada Eska R. Triristanto, yang telah membantu dalam proses pengambilan data di lapangan maupun proses editing manuskrip.

\section{REFERENS|}

Althuwaynee O., F, Pradhan B, Park H., J, \& Lee J., H. (2014). A novel ensemble bivariate statistical evidential belief function with knowledge-based analytical hierarchy process and multivariate statistical logistic regression for landslide susceptibility mapping. Catena, 114, 21-36. DOI: 10.1016/j.catena.2013.10.011

Badan Nasional Penganggulangan Bencana (BNPB). (2012). Waspada Masyarakat pada Bencana Angin Puting Beliung dan Banjir. GEMA BNPB, 3(3). Diakses dari https://bnpb.go.id/berita/gema-bnpb-vol-3-no-32012

Chen, Y., J. Yu., K. Shahbaz., \& E. Xevi. (2009). A GIS-Based Sensitivity Analysis of Multi-Criteria Weights. 18th World IMACS/MODSIM Congress. Cairns, Australia.

Eldrandaly, K. (2013). Developing a GIS-Based MCE Site Selection Tool in ArcGIS Using COM
Technology. International Arab Journal of Information Technology (IAJIT), 10(3). Diakses dari

http://www.philadelphia.edu.jo/newlibrary/articl s/460-computer/31233-1774

Karnawati, D. (2005). Bencana Alam Gerakan Massa Tanah di Indonesia dan Upaya Penanggulangannya. Yogyakarta: Jurusan Teknik Geologi, Universitas Gadjah Mada.

Kementerian Dalam Negeri. (2006). Peraturan Menteri Dalam Negeri nomor 33 Tahun 2006 tentang Pedoman Umum Mitigasi Bencana

Mandal, B., \& Mandal, S. (2018). Analytical hierarchy process (AHP) based landslide susceptibility mapping of Lish river basin of eastern Darjeeling Himalaya, India. Advances in Space Research, 62(11), 3114-3132. DOI: 10.1016/j.asr.2018.08.008

Nahayo, L., Kalisa, E., Maniragaba, A., \& Nshimiyimana, F. X. (2019). Comparison of analytical hierarchy process and certain factor models in landslide susceptibility mapping in Rwanda. Modeling Earth Systems and Environment, 5(3), 885-895. DOI: 10.1007/s40808-019-00575-1

Nugroho, S. P. (2016), Evaluasi Penanggulangan Bencana 2015 dan Prediksi Bencana 2016. Badan Nasional Penganggulangan Bencana (BNPB), Jakarta.

Oh, H. \& J, Lee, S. (2011). Landslide susceptibility mapping on Panaon Island, Philippines using a geographic information system. Environ Earth Sci, 62, 935-951. DOI 10.1007/s12665-0100579-2

Park, S., Choi, C., Kim, B., \& Kim, J. (2012). Landslide Susceptibility Mapping Using Frequency Ratio, Analytic Hierarchy Process, Logistic Regression, and Artificial Neural Network Methods at the Inje Area, Korea. Environ Earth Sci, 68, 1443-1464. DOI: 10.1007/s12665-012$1842-5$

Saaty, T.L. (2008). Decision making with the analytic hierarchy process Int. J. Services Sciences, 1(1), 83. DOI: 10.1504/IJSSCI.2008.017590

Surono, Sudarno, I., \& Toha, B. (1992). Peta Geologi Lembar Surakarta - Giritontro, Skala 1:100.000. Pusat Penelitian dan Pengembangan Geologi, Bandung.

Vahidnia, M. H., Alesheikh, A. A., Alimohammadi, A., \& Hosseinali, F. (2009). Landslide Hazard Zonation Using Quantitative Methods in GIS. International Journal of Civil Engineering, 7(3), 176-189. Diakses dari http://ijce.iust.ac.ir/article-1-289-en.pdf

Yalcin, A. (2008). GIS-based landslide susceptibility mapping using analytical hierarchy process and bivariate statistics in Ardesen (Turkey): comparisons of results and confirmations. Catena, 72, 1-12. DOI: 10.1016/j.catena.2007.01.003. 